\title{
Apolipoprotein C-III
}

National Cancer Institute

\section{Source}

National Cancer Institute. Apolipoprotein C-III. NCI Thesaurus. Code C117099.

Apolipoprotein C-III (99 aa, $\sim 11 \mathrm{kDa}$ ) is encoded by the human APOC3 gene. This protein is involved in the modulation of cellular uptake and metabolism of very low density lipoproteins and chylomicrons. 